\title{
Analysing Customers' Waiting Time Using Discrete-Event Simulation: A Case Study in A University Printing Shop
}

\author{
Tan Wei Mey*, Teoh Kher Nee, Norazura Ahmad \\ ${ }^{1}$ School of Quantitative Sciences, Universiti Utara Malaysia, 06010 Sintok, Kedah, Malaysia. \\ *Corresponding author: norazura@uum.edu.my \\ DOI: https://doi.org/10.37134/jsml.vol7.4.2019
}

Received: 12 October 2018; Accepted: 15 May 2019; Published: 10 July 2019

\begin{abstract}
This paper discusses the application of discrete-event simulation (DES) in modelling the waiting lines in a printing shop located in Universiti Utara Malaysia. The paper demonstrates the methodology used to develop the simulation model of the existing system. The developed model was run to further understand the state of operations in the printing shop. The developed model also facilitates experimenting for a possible alternative solution. The finding of this study has given insight to reduce the waiting time for a better service in the printing shop.
\end{abstract}

Keywords: Waiting lines; Queueing systems, Discrete-event simulation, Printing shop

\begin{abstract}
Abstrak
Makalah ini membincangkan penggunaan simulasi peristiwa-diskret (DES) dalam memodelkan barisan menunggu di sebuah kedai percetakan di dalam Universiti Utara Malaysia. Makalah ini menunjukkan kaedah yang telah digunakan untuk membangunkan model simulasi sistem yang sedia ada. Model simulasi ini telah dibangunkan untuk lebih memahami keadaan operasi di kedai percetakan. Model yang dibangunkan turut memudahkan pengujian untuk mencari penyelesaian alternatif yang wajar. Hasil kajian ini telah memberikan pemahaman yang lebih jelas dalam mengurangkan masa menunggu bagi mencapai perkhidmatan yang lebih baik di kedai percetakan.
\end{abstract}

Kata kunci: Barisan menunggu; Sistem baris gilir; Simulasi peristiwa-diskret; Kedai percetakan

\section{INTRODUCTION}

Most of us have experienced waiting in line in our daily lives. As a customer seeking for service, we always want a service provider with the fastest service rate. On the other hand, a service provider will try at their best to minimize customers' waiting time in order to attract more customers to their premise. A waiting line occurs when there is more demand than the service that can be provided (Agyei, 2015).

In the beginning, the waiting lines problem has been solved using analytical models based on a queueing theory. The queuing theory utilizes mathematical models to compute certain performance measures to improve the flow of entities in the waiting lines (Render, Hannah, Stair \& Hale, 2015). In waiting line systems, customers have to wait during the process to acquire products and services. Besides waiting times, there are three basic components in the queuing theory that characterized a waiting line system: the arrivals, the 
service facilities and the queue discipline. In operations management, applying the knowledge in queuing theory can help the operation managers assess the customers' waiting experience and improve the flow of customers in the system(Chinwuko, Daniel, Ugochukwu \& Obiora; 2014; Gumus, Bubou \& Oladeinde; 2017).

However, as the real waiting line system involves large scale and becomes much more complicated, computer simulation is opted to analyse the systems (Pidd, 2004). The majority of the waiting line simulations are discrete-event simulation (DES) models that focus on identifying the bottlenecks to improve the system's performance (Mustafee, Katsaliaki \& Taylor; 2010). In these DES models, the queuing structure may be noticeable either in the form of jobs waiting to be processed or a stack of vehicles waiting for inspection service at a vehicle inspection centre. In some cases, the queuing structure may be less apparent, as in the deployment of ambulances in a capital city in the country. In this case, the customers are the patients needing pre-hospital treatment while the resources are the ambulances together with their paramedic team.

DES has been widely used to experiment the real situation to evaluate the performance of a system under different configurations of interest. In addition, the what-if analyses in DES allow the modellers to evaluate the impact of proposed changes on the behaviour of the system prior to implementation of the decision (Mat Tahar, 2006). The scope of DES model in this paper is related to a real case scenario of a printing shop in Universiti Utara Malaysia. The shop had an issue with long queue experienced by customers during peak hour. A DES model is developed using Arena software, version 14.5 to analyse the queuing system in the printing shop as well as identifying whether any bottleneck exists in the system. The aim of the study is to identify possible alternative solution for a reasonable fast printing service to customers.

The remaining sections in this paper are structured as follows. In the following sections, we present some related literature and the methodology applied in the study. We also discuss the obtained results from the developed model and the what-if analysis based on a proposed change introduced to the current model. Finally, the last section concludes the study and proposes possible future work resulting from the study.

\section{RELATED LITERATURE}

The waiting line issue is a common problem in service industries (Agyei, 2015; Al-Matar, 2017). The long queue and long waiting time, often consider as a bad image of a company. The long waiting time may be due to some reasons such as the arrival rate, service rate, type of services, time of the day, and efficiency of the server (Sarkar et al., 2011; Kokkinou \& Cranage, 2013). Many researchers have studied the waiting lines problem using either queuing theory or simulation modelling.

For instance, Jayeshkumar, Chadhaury and Jayesh (2012) study about a ticket window service unit of a railway station using queuing theory. A long queue was formed whenever current demand exceeds the existing capacity to serve the ticket. When each window counter was busy, the arriving customers could not receive an immediate ticket. In the study, three different models were developed to estimate the queue length: a singlequeue multi-server model, single-queue single-server and multiple queue multi-server models. Analytical solutions were obtained for all models except for the multiple queues. This is because of the line switching behaviour or jockeying to any available short queue among passengers when the system does not employ a single waiting line. 
Similarly, in a bank setting, Nsude, Elem-Uche and Bassey Uwabunkonye (2017) applied the queuing theory to identify the adequate number of servers required to serve the customers. The result showed that the required servers are 5 instead of 3 at present. The findings suggested that the bank should increase the current servers because service providers will lose customers via reneging and balking when a long queue is formed. Another study conducted by Chinwuko, Daniel, Ugochukwu and Obiafudo (2014) also applied the queuing theory in analysing a queuing system in order to increase the number of servers and provide suggestions to handle the problem of customers' arrival rate.

Although the simple queuing theory able to provide significant performance measures in waiting lines problem, the computation for a complex system may not be practical, since complex systems often involve many variables, which require many assumptions to make the model analytically tractable. Therefore, many researchers opt to simulation model that embedded the queuing theory by running the model using computer software. Many studies in the service area used DES approach to solve the problem related to waiting time (Mahapatra et al., 2003; Takakuwa \& Shiozaki, 2004; Eskandari, Riyahifard, Koshravi \& Geiger, 2011).

For instance, in a health care system, Mahapatra et al., (2003) applied DES approach to model the staffing plan of an emergency department by evaluating alternative schedule in order to minimize the patients' average waiting time. Young (2005) applied DES approach to assist healthcare organizations explore alternative patient queuing and flow. Several researchers have also used DES approach for capacity planning in critical departments in hospitals (VanBerkel \& Blake, 2007; Kumar \& Shim, 2010). There are also studies that used the simulation technique to revise queuing policy and solve waiting list problem (Harper \& Shahani, 2002; Harper \& Gamlin, 2003).

In transportation, Byeon (2006) conducted a simulation study to reduce the waiting time and operating cost for consolidated transportation. In addition, Hsu (2010) developed a DES model to evaluate the transfer waiting time for a connecting service at multi-modal stations. Trakoonsanti (2016) and Guizzi et al (2009) demonstrated the use of DES approach to decrease the queue during check-in process and prevent delay at an airport terminal.

The literature review has highlighted the capability of DES approach in imitating the real system for better decision making. Therefore, to identify the bottlenecks in the printing shop that may affect customers' waiting time, we develop a DES model using the Arena Simulation software.

\section{METHODOLOGY}

\section{System Description}

The printing shop operates from 10 a.m. to 4 p.m. on weekdays. It provides multiple services like photocopying, printing, hardcover binding and laminating. In this study, we mainly focused on the queuing process of printing service as displayed in Figure 1. The printing shop provides four computers at the front desk for customers to download their materials for printing purposes. As customers arrive, they need to queue for the computers before printing. After printing, customers will move to a specific area of the front desk for payment. 


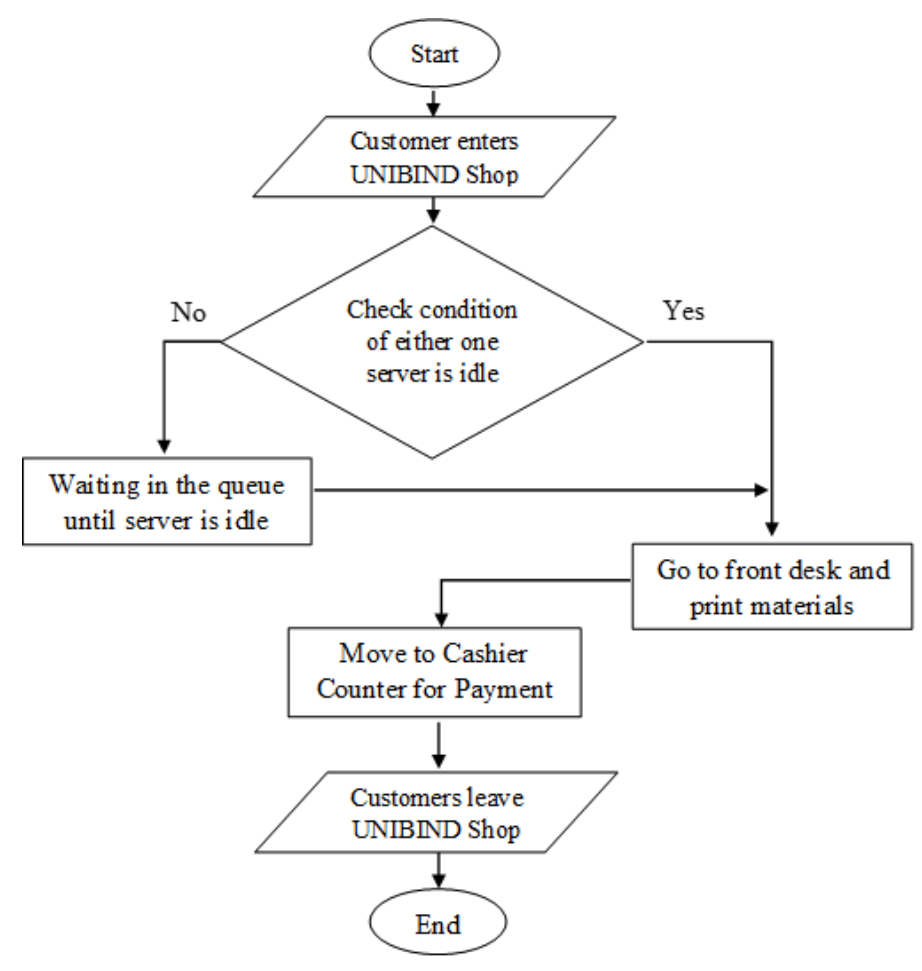

Figure 1. The Overall Customer Flow of UNIBIND Shop

The most common problem at the printing shop is when customers overcrowded at the front desk during peak hour for various services. The printing shop has three staffs attending to different customers' demands such as lamination, binding, photocopy, while at the same time collecting payment. During the peak hour, long queue may build up as customers' arrivals exceed the capacity of the resources in the printing shop. Consequently, customers may move to other printing shops, to get a faster services than waiting in the long queue.

\section{Data Collection}

In order to develop the DES model, data was collected through interviews with the staffs and field observation. The processing time for each activity are not available and thus, need to be collected manually. For instance, the arrival time and departure time of each customer are identified and recorded through direct observation method. Based on the three granted days from the shop owner, a sample data was collected to determine the suitable distribution functions that will be used in the simulation modelling. The unit time of the data was recorded based on minutes. Based on 73 observations, the average waiting time in the printing queue is approximately equal to 4.8 minutes.

\section{Model Development}

According to Ahmad et al. (2012), there are several steps need to be followed to build a proper DES model. In this study, the similar steps as in Figure 2 have been applied to build the printing service model in the printing shop. 


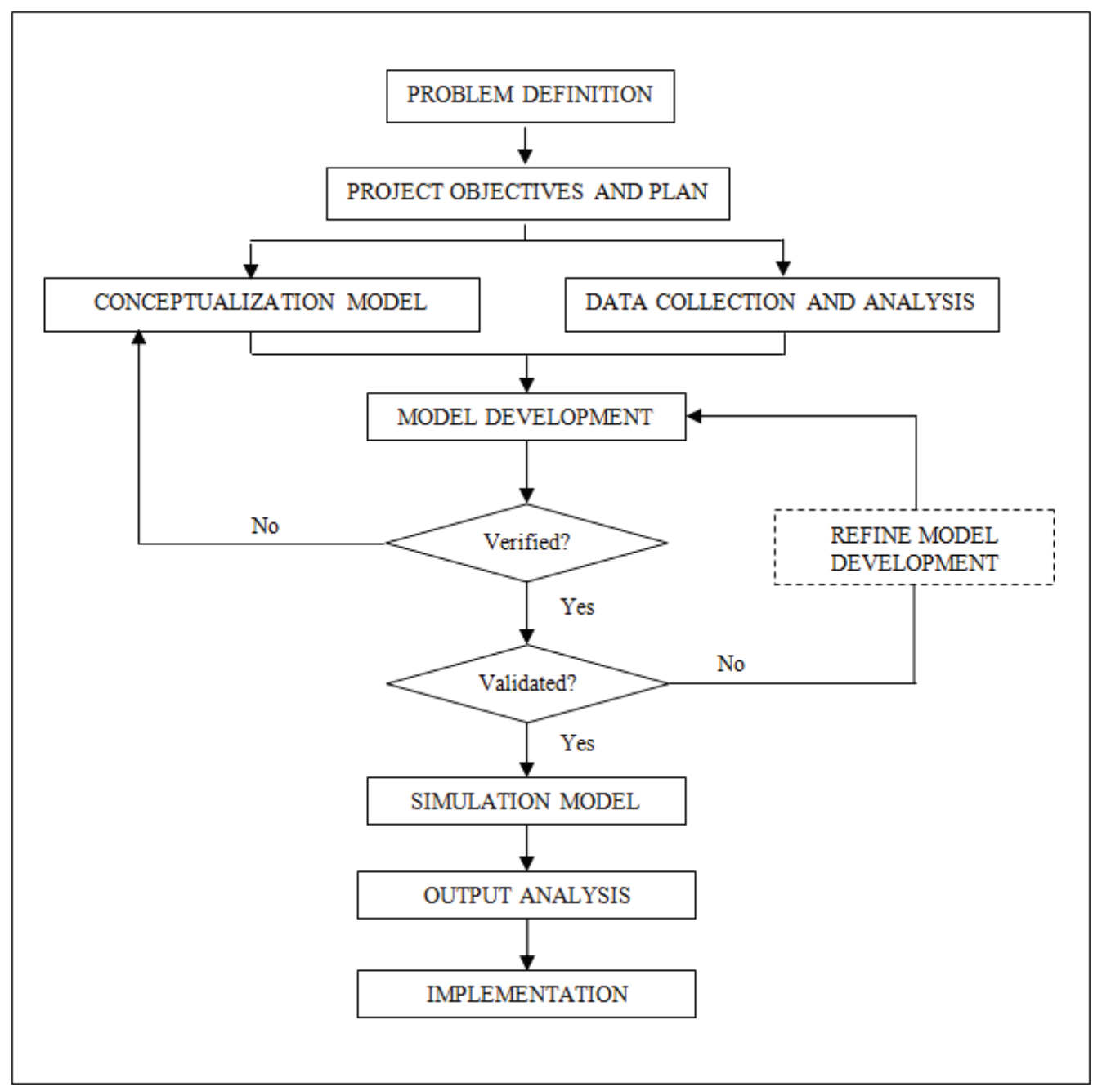

Figure 2. The DES modelling steps

The development of the model begins with studying and investigating the system through direct observation of customer flow and the relationship of each activity with the required resources. Through observations and interviews, the conceptual model is developed. The conceptual model is then translated into a simulation model using the Arena software. The collected data were inserted into Arena Input Analyzer to determine their appropriate distribution. The appropriate probability distribution provided by the Input Analyzer is as shown in Table 1.

Table 1. The distribution expression of each input data using Input Analyzer

\begin{tabular}{lcc}
\hline Input Data & Distribution & Expression \\
\hline Interarrival Time & Exponential & $0.5+$ EXPO $(2.63)$ \\
Service time for printing & Lognormal & $0.5+$ LOGN $(1.4,1.4)$ \\
Service time for payment & Lognormal & $1.5+$ LOGN $(8.48,10.4)$ \\
\hline
\end{tabular}

Those distributions were inserted into Arena modules and the modules were connected based on the conceptual model. Three types of basic modules, which are create module, process module and dispose module are used in the model. In addition, two types 
of advanced transfer modules i.e station module and route module were also used to create the model logic as displayed in Figure 3.

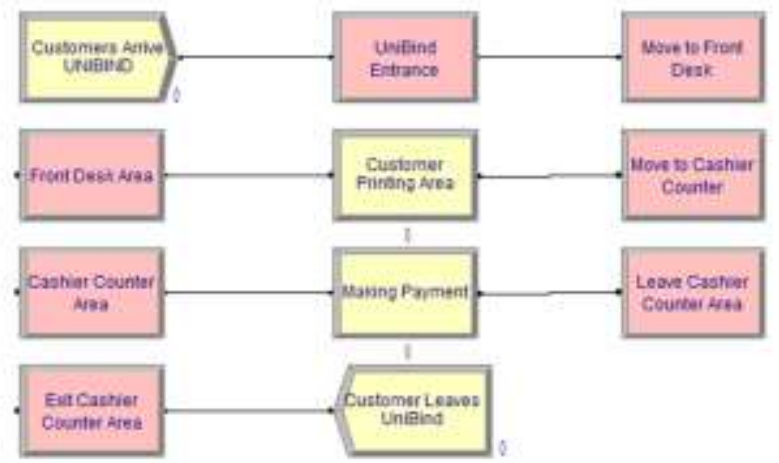

Figure 3. The Model Logic of the Printing Service

\section{Verification and Validation}

The function "Check Model" in Arena software is utilized to verify the developed model (Figure 4). The result showed that there was no error or warning in the model which indicated that our model was correctly implemented in the computer.

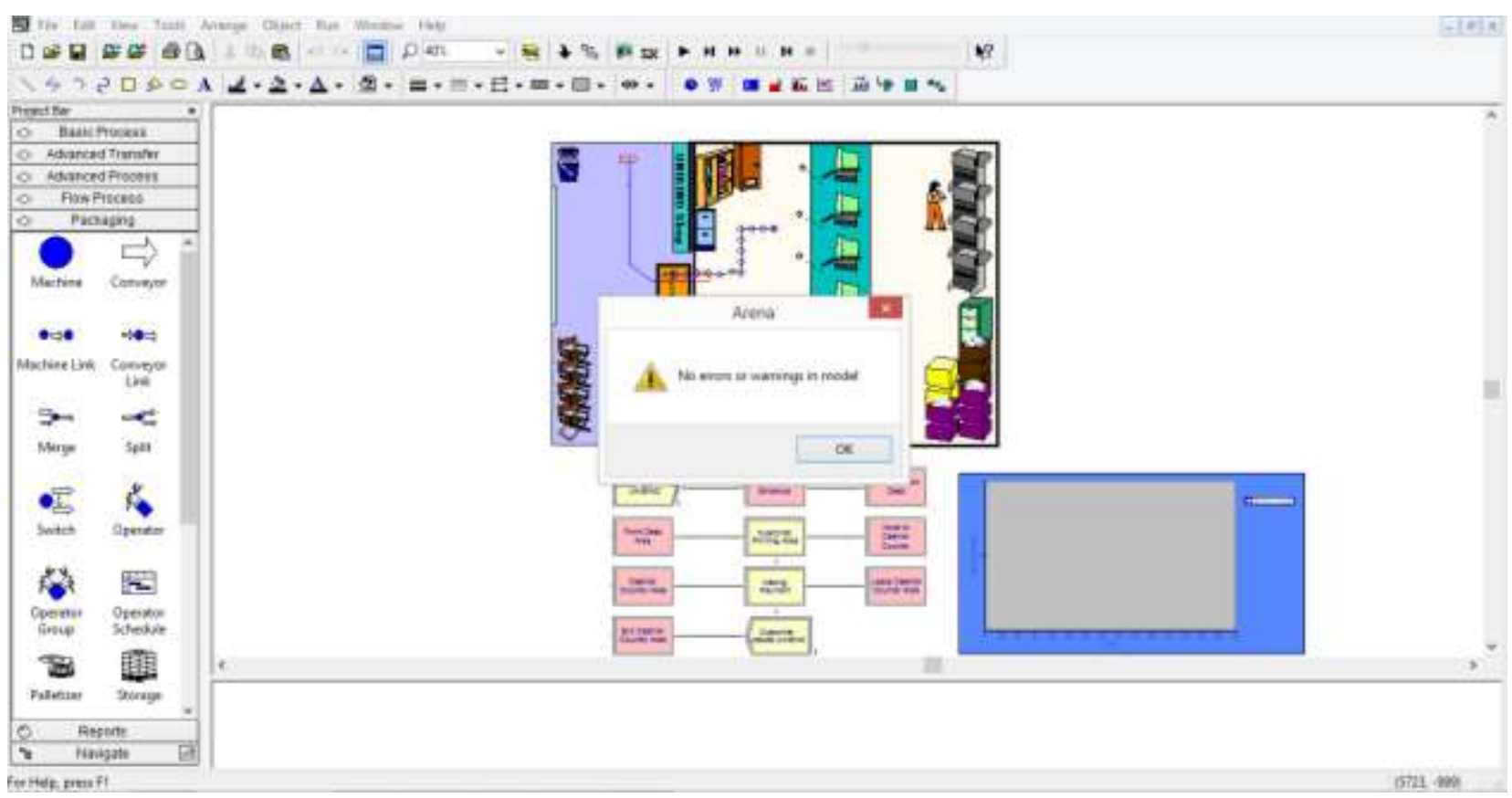

Figure 4. The "Check Model" of Simulated Model

To ensure our model is an accurate representation of the real system, validation of the simulation model was conducted. However, the result showed the half-width was insufficient for one replication after inserting the expression and distribution showed in Table 1 into the model. It indicated the model was not in the steady-state analysis (Carson, 2002). Thus, the model is required to be run with more replication. A $95 \%$ reliability ( $\alpha=$ 0.05 ) and an accuracy that yields an ideal half with confidence interval, $\boldsymbol{h} \boldsymbol{w} *$ of 6 is decided in the beginning. Then, the model was run for six replications and the results are shown in Table 2. 
Table 2. Result of Six Replications of the printing shop Model

\begin{tabular}{cc}
\hline Replication / n & Average waiting time / mins \\
\hline 1 & 14.090 \\
2 & 8.8340 \\
3 & 6.7537 \\
4 & 1.5492 \\
5 & 2.3932 \\
6 & 2.9140 \\
\hline
\end{tabular}

To identify the right number of replications, we computed the $(1-\alpha) \%$ confidence interval using the following equation:

$$
\bar{x}-t_{n-1,1-\alpha / 2} \frac{s}{\sqrt{n}} \leq \mu \leq \bar{x}+t_{n-1,1-\alpha / 2} \frac{s}{\sqrt{n}}
$$

where $t_{n-1,1-\alpha / 2}$ is the upper 1- $\alpha / 2$ critical point of the $t$ distribution with $n-1$ degrees of freedom. Equation (1), which is also known as the $t$ confidence interval is recommended over $\mathrm{z}$ confidence level because it offers larger coverage that is closer to the desired level 1$\alpha$ (Law \& Kelton, 2000). Based on the six replications, the critical point of $t_{5,0.975}$ is given as 2.571 obtained from the $t$ Distribution Table. The descriptive statistics yields from the six replications are as shown in Table 3.

Table 3. Descriptive statistics from the six replications

\begin{tabular}{lllll}
\hline $\begin{array}{c}\text { Performance } \\
\text { measure }\end{array}$ & Mean & $\begin{array}{c}\text { Standard } \\
\text { Deviation }\end{array}$ & $\begin{array}{c}\text { Half width } \\
\text { confidence } \\
\text { interval }\end{array}$ & $\begin{array}{c}t \text { confidence } \\
\text { interval }\end{array}$ \\
\hline Waiting time & 6.0890 & 4.8237 & 5.063 & $1.026 \leq \mu \leq 11.152$ \\
\hline
\end{tabular}

Notice that half width $(h w)$ for the waiting time is less than the initial half width $\left(\boldsymbol{h} \boldsymbol{w}^{*}=6\right)$ decided in the beginning of the simulation run. As $h w<\boldsymbol{h} \boldsymbol{w}^{*}$, six replications in the preliminary run are considered appropriate for the developed model. Based on the collected data, the average waiting time per customer in printing queue was approximately 4.8 minutes. To ensure that the result of the simulation model is adequate to represent the real system, we conduct the hypothesis testing as follows:

$$
\begin{aligned}
& \mathrm{H}_{0}: \mathrm{E}(\mathrm{X})=4.8 \text { minutes } \\
& \mathrm{H}_{1}: \mathrm{E}(\mathrm{X}) \neq 4.8 \text { minutes }
\end{aligned}
$$

$\alpha=0.05, \mathrm{n}=6$, Sample mean, $\mathrm{X}_{\text {bar }}=6.089$, Standard deviation, $\mathrm{S}=4.824, t_{\text {critical }}=2.571$

Test statistic, $\mathrm{T}_{0}=\left\{\left(\mathrm{X}_{\mathrm{bar}}-\mathrm{X}\right) / \mathrm{S}\right\} * \sqrt{n}$

$$
\begin{aligned}
& =\{(6.089-4.8) / 4.824\} * \sqrt{6} \\
& =0.6545
\end{aligned}
$$

Since $\left|\mathrm{T}_{0}\right|<\mathrm{T}_{\text {critical }}, 0.6545<2.571$, the $\mathrm{H}_{0}$ is not rejected at the 0.05 significance level. Therefore, it can be concluded that the model is adequate in its prediction of average customer waiting time.

\section{ANALYSIS OF RESULTS}

Based on the output performance measures of four computers as displayed in Table 4, the system was replicated for six times with a total duration of 240 minutes. 
Table 4. Output Performance Measures for Four Resources

\begin{tabular}{lc}
\hline Description & Results \\
\hline Replication length of system & 6 \\
Average total time in system (minutes per customer) & 20.3532 \\
Average waiting time in printing queue (minutes per customer) & 4.3270 \\
Average waiting time in payment queue (minutes per customer) & 1.4824 \\
Average number of customer in printing queue (customer) & 1.5332 \\
Average number of customer in payment queue (customer) & 0.4744 \\
Number of customer enter system (customer) & 80.5000 \\
Number of customer leave system (customer) & 71.8333 \\
Utilization of computer 1 & 0.7792 \\
Utilization of computer 2 & 0.7901 \\
Utilization of computer 3 & 0.7915 \\
Utilization of computer 4 & 0.7908 \\
Utilization of staff & 0.5812 \\
\hline
\end{tabular}

There were approximately 81 customers entered the system and the average total time spent in the system is 20.3532 minutes. The process included waiting in queue to get served in printing area, making payment and leaving the system after service. Each customer may proceed directly to the printing area if either one of the four computers was idle. On the other hand, if all computers were busy, customers needed to wait in the queue. It was found that every customer spent an average waiting time of 4.3270 minutes in the printing queue and 1.4824 minutes in the payment queue. The average number of customers in the printing queue and the payment queue was approximately 2 customers and 1 customer respectively. After making the payment, 72 customers manage to leave the system. It showed that 9 customers are considered as work in progress. In addition, all resources in the system had a good utilization rate, which above $50 \%$. The utilization of computer 1 , computer 2, computer 3, computer 4 and staff were $77.92 \%, 79.01 \%, 79.15 \%, 79.08 \%$ and $58.12 \%$ respectively.

Table 5. Output Performance Measures for Five Resources

\begin{tabular}{lc}
\hline Description & Results \\
\hline Replication length of system & 6 \\
Average total time in system (minutes per customer) & 16.6407 \\
Average waiting time in printing queue (minutes per customer) & 0.6475 \\
Average waiting time in payment queue (minutes per customer) & 1.5058 \\
Average number of customer in printing queue (customer) & 0.2039 \\
Average number of customer in payment queue (customer) & 0.4743 \\
Number of customer enter system (customer) & 78 \\
Number of customer leave system (customer) & 73 \\
Utilization of computer 1 & 0.6528 \\
Utilization of computer 2 & 0.6249 \\
Utilization of computer 3 & 0.5947 \\
Utilization of computer 4 & 0.6221 \\
Utilization of computer 5 & 0.6215 \\
Utilization of staff & 0.5533 \\
\hline
\end{tabular}

Based on the existing system, there were four computers provided to customers for printing purposes. The average total time in system was 20.3532 minutes, which composed of 4.3270 minutes of average waiting time in the printing queue per customer and 1.4824 minutes of average waiting time in the payment queue. After adding an extra computer into the system (Table 5), the average total time in the system and average waiting time in printing queue decreased to 16.6407 minutes per customer and 0.6475 minutes per customer 
respectively. As expected, the utilization rate of each resource was also decreased, which is more or less than $60 \%$. The average number of customers in the printing queue also reduced from approximately two customers to one customer only. The reducing of people in the printing queue line will create a better waiting environment for customers, as not more than 15 customers may wait in the waiting area.

\section{LIMITATIONS}

The first limitation of this study is the period of data collection granted by the shop owner. Only three days were allocated to collect the processing times and the number of customers. Therefore, only a small number of observations could be observed and collected. The second limitation was a knowledge limitation in different fields. The suggestion given in the research solely focused on the technical process improvement. However, more aspects should be analysed, such as from finance, organizational management and internal building structure design point of view so that our suggestions would be more realistic and practical to the real system. For future research, those aspects must be studied in details and to be included in the model to present more accurate model.

\section{CONCLUSION}

The evaluation of the queuing process of a business is essential in order to provide customers better experiences in receiving the services. A DES model was developed in this study to simulate the queuing process of a printing shop. The analysis of the existing queuing process showed that customers waited for an average 4 to 5 minutes to access the computer for printing purpose. Hence, a solution was suggested by adding one computer to the existing system. The increase in the number of resources from four computers to five computers had reduced the waiting time in the printing queue to 0.6475 minutes per customer. If the suggestion is implemented, it may provide better experiences to customers while receiving services in the printing shop.

\section{ACKNOWLEDGEMENT}

The authors would like to thank all parties that involved directly and indirectly in the SQQP4073 research project. Special thanks to the case study printing shop for the permission to collect the data during the operating hours and sharing the operation information with us.

\section{REFERENCES}

Agyei, W., Asare-Darko, C. \& Odilon, F. (2015). Modeling and analysis of queuing systems in banks: A case study of Ghana Commercial Bank Ltd. Kumasi Main Branch. International Journal of Scientific \& Technology Research, 4(7), 160-163.

Ahmad, N., Ghani, N., Kamil, A. A., Mat Tahar, R., \& Teo, A. H. (2012). Evaluating emergency department resource capacity using simulation. Modern Applied Science, 6(11), 9-19.

Al-Matar, N. (2017). Theories and applications related to queuing systems. International Journal of Advances in Electronics and Computer Science, 4(2), 14-17.

Byeon, E. S. (2006). Simulation study of consolidated transportation. In Proc. of the 6th WSEAS International Conference on Simulation, Modeling and Optimization, 582-585. 
Carson, J. S. (2002). Model verification and validation. Proceedings of the 2002 Winter Simulation Conference, Ed. by E. Yücesan et al. (San Diego, CA, 2002), pp. 52-58.

Chinwuko, C.E., Danial, E.C., Ugochukwu, O.P. \& Obiafudo O. J. (2014). Analysis of a queuing system in an organization (a case study of First Bank PLC, Nigeria). American Journal of Engineering Research, $3(2), 63-72$.

Eskandari, H., Riyahifard, M., Khosravi, S. \& Geiger, C. D. (2011). Improving the emergency department performance using simulation and MCDM methods. Paper presented at the 2011 Winter Simulation Conference, 11-14 December 2011, Grand Arizona Resort Phoenix, Arizona, 1211-1222. Retrieved from IEEE Xplore Digital Library.

Guizzi, G., Murino, T., \& Romano, E. (2009). A Discrete Event Simulation to model Passenger Flow in the Airport Terminal. Mathematical Methods and Applied Computing, 427-434.

Gumus, S., Bubou, G. M. \& Oladeinde, M. H. (2017). Application of queuing theory to a fast food outfit: A study of Blue Meadows Restaurant. Independent Journal of Management and Production, 8(2), 441-458.

Harper, P. R. \& Gramlin, H. M. (2003). Reduced outpatient waiting times with improved appointment scheduling: A simulation modeling approach. OR Spectrum, 25, 207-222.

Harper, P. R., \& Shahani, A. K. (2002). Modelling for the planning and management of bed capacities in hospitals. Journal of the Operational Research Society, 53, 11-18.

Hsu, S. C. (2010). Determinants of passenger transfer waiting time at multi-modal connecting stations. Transportation Research Part E: Logistics and Transportation Review, 46(3), 404-413.

Kokkinou, A., \& Cranage, D. A. (2013). Using self-service technology to reduce customer waiting times. International Journal of Hospitality Management, 33(1), 435-445.

Kumar, A. \& Shim, S. J. (2010). Centralization of Intensive Care Units: Process reengineering in a hospital. International Journal of Engineering Business Management, 2(1), 35-40.

Mahapatra, S., Koellig, C., Patvivatsiri, L., Fraticelli, B., Eitel, D. \& Grove, L. (2003). Pairing emergency severity index level triage data with computer aided system design to improve emergency department access and throughput. Proceedings of the 2003 Winter Simulation Conference. 2003. pp. 1917-1925.

Mat Tahar, R. (2006). A practical approach to computer simulation modelling. Serdang: Universiti Putra Malaysia Press.

Mustafee, N., Katsaliaki, K., \& Taylor, S. J. E. (2010). Profiling literature in healthcare simulation. Simulation, 86(8-9), 543-558.

Nsude, F.I., Elem-Uche, O. \& Uwabunkonye, B. (2017). Analysis of multiple-queue multiple-server queuing system: a case study of First Bank Nigeria Plc, Afikpo Branch. International Journal of Scientific \& Engineering Research, 8(1), 1700-1709.

Patel, J.J., Chadhaury, R. M. \& Patel, J. M. (2012). Queuing theory and its application at railway ticket window. Journal of Information, Knowledge and Research in Information Technology, 2(1), 99-112.

Pidd, M. (2004). Computer simulation in management science. England: John Wiley \& Sons Ltd.

Render, B., Stair, R. M., Hanna, M. E. \& Hale, T. S. (2015). Quantitative analysis for management (12th e.d.). England:Pearson Education Limited.

Sarkar, A., Mukhopadhyay, A. R., \& Ghosh, S. K. (2011). Improvement of service quality by reducing waiting time for service. Simulation Modelling Practice and Theory, 19(7), 1689-1698.

Takakuwa, S., \& Shiozaki, H. (2004). Functional Analysis for operating emergency department of a general hospital. Paper presented at the 2004 Winter Simulation Conference, 5-8 December 2004, Washington Hilton and Towers, Washington. Retrieved from IEEE Xplore Digital Library.

Trakoonsanti, L. (2016). A Process Simulation Model of Airline Passenger Check - In. Universal Journal of Management, 4(5), 265-276.

VanBerkel, P.T. \& Blake, J. T. (2007). A comprehensive simulation for wait time reduction and capacity planning applied in general surgery. Health Care Manage Sci, 10, 373-385. doi:10.1007/s10729-0079035-6

Young, T. (2005). An agenda for healthcare and information simulation. Health Care Management Science, $8,189-196$ 